\title{
Promotion of health, sustainability and social development of a vulnerable community
}

Promoção da saúde, sustentabilidade e desenvolvimento social de comunidade vulnerável

Promoción de la salud, sostenibilidad y desarrollo social de la comunidad vulnerable

\section{Viviane Silva de Jesus',II, Samylla Maira Costa Siqueira', Climene Laura de Camargo', Ridalva Dias Martins Felzemburgh', Maria Carolina Ortiz Whitaker', Márcia Lúcia dos Santos', Carolina Larrosa de Almeida"}

\author{
' Universidade Federal da Bahia. Salvador, Bahia, Brazil. \\ "Faculdade Adventista da Bahia. Cachoeira, Bahia, Brazil.
}

How to cite this article:

Jesus VS, Siqueira SMC, Camargo CL, Felzemburgh RDM, Whitaker MCO, Santos ML, et al.

Promotion of health, sustainability and social development of a vulnerable community.

Rev Bras Enferm [Internet]. 2018;71(6):3109-14. DOI: http://dx.doi.org/10.1590/0034-7167-2017-0381

Submission: 08-22-2017

Approval: 04-19-2018

\begin{abstract}
Objective: to report the experience of research phases on promoting sustainable development based on social technologies with palm fiber artifacts in a vulnerable community. Method: this is an experience report that describes the phases of a multiprofessional project that sought sustainable development, and was conducted with inhabitants from a vulnerable community. Results: the actions were developed in four phases: exploratory, planning, implementation and evaluation. These phases encompassed a situational diagnosis, planning and performing health education workshops, training meetings, production of handcrafted window shutters with insulation and acoustic comfort. The most emphatic result was the possibility of a new source of income. Final Considerations: the project actions favored the individual and collective empowerment of the participants regarding their health, especially considering the recovery of self-esteem, valuation of traditional knowledge and a new source of income.

Descriptors: Sensitive Populations, Community Health Nursing, Conservation of Natural Resources, Social Planning; Health Education.
\end{abstract}

\section{RESUMO}

Objetivo: relatar a experiência das fases de uma pesquisa sobre desenvolvimento social, sustentabilidade e promoção da saúde. Método: trata-se de um relato de experiência no qual se discorre a respeito das fases de um projeto de pesquisa desenvolvido por um grupo de profissionais e alunos de enfermagem, engenharia e arquitetura para o desenvolvimento social, a promoção da saúde e da sustentabilidade de uma comunidade vulnerável. Resultados: a pesquisa se deu em quatro fases - exploratória (diagnóstico, aproximação e identificação das potencialidades humanas e ambientais); planejamento (das ações a partir das demandas dos participantes); implementação (construção do espaço para execução das atividades do projeto); e avaliativa (avaliação das três fases citadas a fim de manter ou modificar ações). Considerações finais: as ações do projeto favoreceram o empoderamento individual e coletivo dos participantes do projeto no que tange à saúde, sobretudo em aspectos relacionados ao resgate da autoestima, à valorização do saber tradicional e à fonte de renda.

Descritores: Populações Vulneráveis; Enfermagem em Saúde Comunitária; Desenvolvimento Sustentável; Desenvolvimento Social; Promoção da Saúde.

\section{RESUMEN}

Objetivo: relatar la experiencia de las fases de una investigación sobre desarrollo social, sostenibilidad y promoción de la salud. Método: se trata de un informe de experiencia en el que discurren las fases de un proyecto de investigación desarrollado por profesionales y estudiantes de Enfermería, Ingeniería y Arquitectura para el desarrollo social, promoción de la salud y la sostenibilidad comunitaria de la comunidad vulnerable. Resultados: la investigación se dio en cuatro fases: exploratoria (diagnóstico, aproximación e identificación del potencial humano y ambiental), planificación (se planeó las acciones a partir de las demandas de los participantes), implantación (construcción del espacio para la ejecución de las actividades del proyecto) y 
evaluación (evaluación de las tres fases citadas para mantener o modificar acciones). Consideraciones finales: De las acciones del proyecto favoreció el empoderamiento individual y colectivo de los participantes en relación con la salud, especialmente en sus aspectos relacionados con el rescate de la autoestima, la apreciación de los conocimientos tradicionales y la fuente de ingresos.

Descriptores: Poblaciones Vulnerables; Enfermería en Salud Comunitaria; Conservación de los Recursos Naturales; Cambio Social; Promoción de la Salud.

\section{CORRESPONDING AUTHOR Viviane Silva de Jesus E-mail: vivi_humaniza@hotmail.com}

\section{INTRODUCTION}

The lack of investments to improve the lives populations in vulnerable conditions contributes to their permanence in a condition of exclusion and marginalization, especially when considering public policies, quality health care and social actions. Such condition hinders economic growth and social development ${ }^{(1)}$.

In this study, vulnerability is not considered exclusively as economic disparities and differences in morbidity and mortality rates among population groups, but as a condition of physical and/or emotional suffering derived from oppression and exclusion mechanisms based on cultural, gender and race discrimination that cause social inequalities and affect the health conditions of individuals and the community ${ }^{(2)}$.

Considering that health, in its broad concept, is a result from several conditions such as food, housing, education, income, environment, work, transportation, employment, leisure, freedom, access and possession of land and access to health services, developing intersectoral policies (economic, employment, income, housing, education, etc.) to combat inequalities and improve the lives of vulnerable groups is very important ${ }^{(3-5)}$.

Based on this idea, collective actions focused on promoting health and social ${ }^{(6)}$ transformations must be developed and result in the valorization of human potentialities and of raw materials available. These actions must ensure the participation and empowerment of populations and enable a feeling of belonging and of being the subject of his/her own actions in individuals. In this perspective, the multiprofessional activity - through the participation of nursing professionals and the support of professionals from other fields of knowledge (Chemical Engineering, Civil Engineering, Architecture, among others) - is fundamental for social development, seeking the promotion of social development of the studied community.

Social Technologies are processes that can be replicated in different scenarios, with the interactive participation of people with different theoretical/technical/scientific knowledge who can aggregate to the performance of a community that holds popular knowledge, resulting in effective solutions for social transformation, with the possibility of generating work and income ${ }^{(1,7)}$.

The innovation on the application of social technologies to the actions described in this article is the convergence of these with an emphasis on the prevention of diseases through the development of health education practices, allowing sustainability. This approach constitutes a political-pedagogical process that provides the concepts of critical and reflexive thinking to individuals, leading them to autonomy and emancipation as subjects capable of proposing and having opinions on health decisions to take care of themselves, their family and community ${ }^{(7)}$.
Therefore, this theme is relevant due to the confluence of health actions with social technologies in the perspective of promoting socioenvironmental development. The objective of this study is to report the experience of the research phases that sought to promote the sustainability and social development of vulnerable populations using social technologies and health education actions.

\section{OBJECTIVE}

To report the experience of the research phases of a study that sought the sustainability, social development and promotion of health.

\section{METHOD}

\section{Types of study}

This is an experience report about the execution of a research project with multiprofessional, intersectoral and interinstitutional characteristics, having as participants approximately 50 community members and 30 members of the multiprofessional team, composed of nurses, architects, engineers and students of these areas.

\section{Work team}

The multiprofessional character derives from the involvement of professionals from different fields of knowledge, such as nursing, engineering, architecture, pedagogy and psychology; the intersectoral character from the participation of the non-governmental organization Association of the Inhabitants of Moreré and Monte Alegre (AMAMOS - Associação dos Moradores de Moreré e Monte Alegre) and of a private company specialized in audio and acoustic architecture projects (AUDIUM - Áudio e Acústica); the interinstitutional character stems from the association between several educational institutions (Universidade Federal da Bahia - UFBA, Universidade Estadual de Maringá - UEM, Universidade Estadual de Montes Claros - UNIMONTES and Universidade Federal de Sergipe UFS). Considering the participatory aspect, the participants were protagonists by highlighting their demands, which aspired health education actions and the need of an activity to generate income.

\section{Experience period and location}

The action research started in March 2006 and continues until nowadays in Moreré, a neighborhood in Ilha de Boipeba, located about $300 \mathrm{~km}$ from the capital of Bahia, Brazil. Despite being rich in natural resources, this community is characterized by the social vulnerability that affects most of its inhabitants, whom are deprived of public goods, especially those related to health and education. In addition, the main economic activities of this community are fishing and tourism, which does not absorb the local workforce. 
The epidemiological diagnosis conducted during the visits found that $85 \%$ of the houses have a septic tank and $100 \%$ do not have access to drinking water supply, nor are served by a sewage system.

In general, the population can be divided in two groups: a) inhabitants who own small businesses and the hotel chain; and b) inhabitants whose income comes from fishing and tourism. The latter live on the neighborhood outskirts, under precarious habitation, food and health conditions.

\section{Description of research development}

The research was developed considering the following phases: 1) Exploratory: this phase was used to identify the problem, and the situation and the residents' potentialities were diagnosed, in addition to awareness-raising actions for the research participants using health education workshops; 2) Planning: in this phase, the themes to be developed in health education workshops were outlined, being based on the demands expressed by the inhabitants. In addition, meetings with the participation of the multidisciplinary team and community residents were held to engage the participants in the planning activities; 3) Implementation: a physical space had to be built so the planned action could be implemented, i.e., the sustainable production of handicrafts produced using two kinds of palm fiber (piassava and dendê). Training meetings were also held in this phase, the themes were selected by community members during the implementation phase. The meetings introduced the development of social technologies to promote sustainability and health. In the end of this stage, the inhabitants had products ready for commercialization in the acoustic architecture market; 4) Evaluation: this phase occurred immediately after the end of the implementation phase. It was based on a survey of the participants' perception of their process and results achieved. The action is still ongoing, being based on meetings and seminars, in which community members, researchers and volunteers participate to discuss strategies for improvement and new technological proposals.

\section{Ethical aspects}

This research met the criteria of Resolution 466/2012 and was submitted to the Research Ethics Committee of the School of Nursing of the Universidade Federal da Bahia through the Brazilian database of scientific research (Plataforma Brasil), being authorized under opinion $n^{\circ} 367.474-2013$. The research was also authorized by local entities, namely, the Educational and Cultural Charitable Associations of Ilha da Maré (ABECIM - Associação Beneficente Educacional e Cultural de Ilha da Maré) and the Association of the Inhabitants of Moreré and Monte Alegre (AMAMOS), being evaluated every six months by the funding institutions and participating members themselves.

\section{RESULTS}

During the project development, it was possible to understand that, although different, all phases are interrelated to each other, as presented below:

\section{1) Exploratory phase}

The initial idea to approach the community was the development of health education activities to raise the inhabitants' awareness about the research proposal, the diagnosis of environmental and health conditions and the idea of sustainable development. For such, the research team made technical visits to identify community leaders (presidents of associations, religious leaders, educators, members of formal and informal health networks) so they could intermediate the relation between the multiprofessional team and community members.

During visits to the island, the researchers identified the existence of human and environmental potentialities that would allow the sustainable development of the community through the production of artifacts made using widely available raw materials found at the location. Environmental potentials are related to the richness of the local flora and fauna; being located at Costa do Dendê, Moreré's community has large quantities of palm fibers, especially dendê and piassava. Human potentials are represented by traditional forms of work developed in the community, like the manufacturing of several household items (Figure 1).

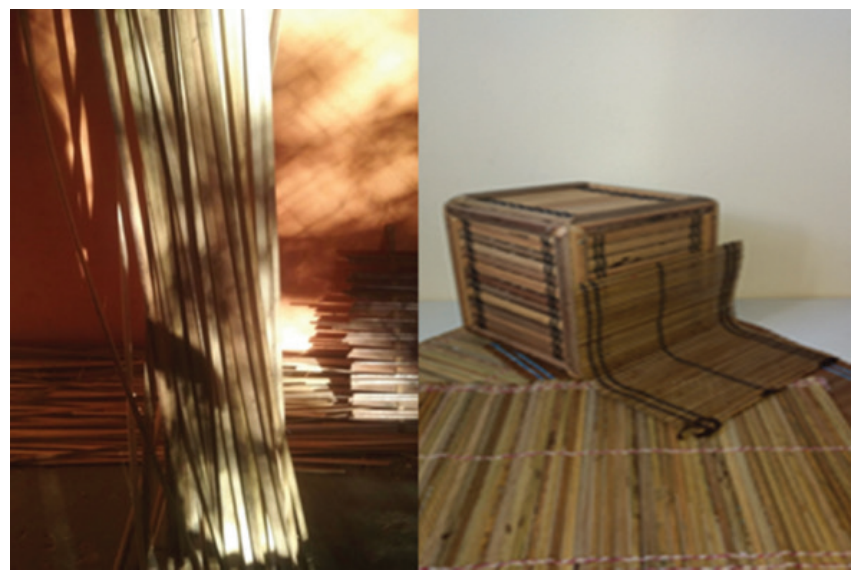

Figure 1 - Dendê fibers found in the community and crafts made from it, Moreré, Bahia, Brazil, 2006

\section{2) Planning phase}

This phase comprised the meetings between the multiprofessional team and community inhabitants. The meetings were used to plan the health education workshops to be conducted in the implementation phase, focusing on themes suggested by the community; thus, characterizing the inhabitants' social participation and autonomy. Meetings with the research participants were also held so they could be engaged in the planning of actions, allowing the situational diagnosis to be presented, as well as the survey of the main problems and possible solutions, discussion of the proposed work and the construction of the training and community production plan.

\section{3) Implementation phase}

The implementation phase encompassed four different practices: 1) the first was conducted by the participants themselves, the construction of a physical space to execute the planned project actions, such as the production of acoustic artifacts, health education workshops and training meetings; 2) the workshops were occurred concomitantly to the sustainability actions. These workshops focused on themes raised by the community and were conducted by professors and undergraduate students of 
the health area from UFBA and UFS. Self-care, environmental protection, sexual and reproductive health can be highlighted as some themes discussed; 3) Training meetings was carried out. They were conducted by people from higher education institutions and community members, who had their traditional knowledge recognized. The results were exchanges between academic and common-sense knowledge. Among the themes approached in the training sessions some can be highlighted: notions of sustainable development; interpersonal relationships; notions of entrepreneurship; customer service; techniques to manufacture window shutters and other household items using raw materials found in the region - inhabitants whom had skills in artisanal production were responsible for this session; manufacture of acoustic plasters; basic accounting techniques; basic selling techniques; and the importance of using personal protective equipment. 4) Manufacture of acoustic artifacts to introduce such products into the market.

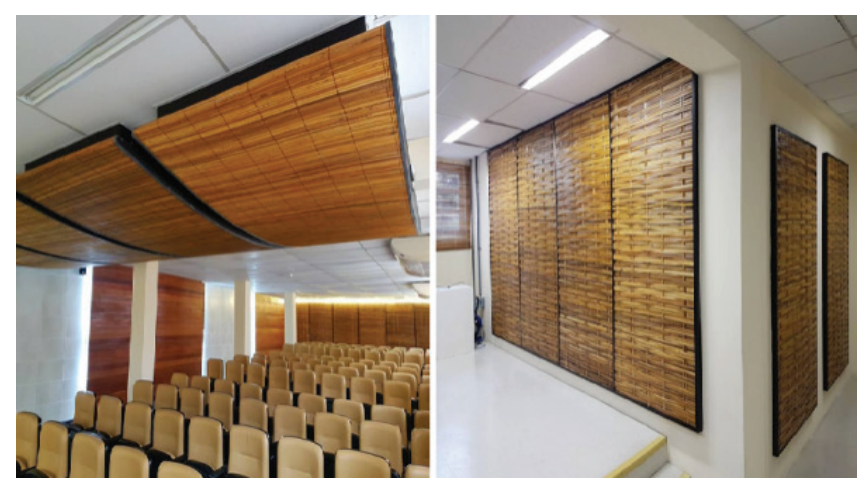

Figure 2 - Handcrafted insulated shutters for acoustic comfort in the auditorium of the School of Nursing of Universidade Federal da Bahia - UFBA, Salvador, Bahia, Brazil, 2016

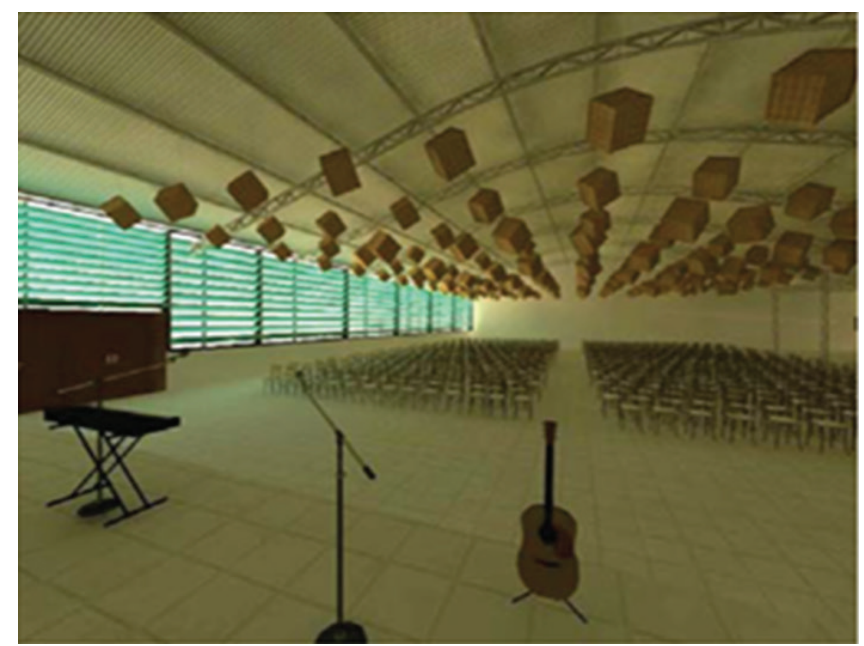

Figure 3 - Cubes for insulation and acoustic comfort in a church, Lauro de Freitas, Salvador, Bahia, Brazil, 2016

Regarding the fourth practice, it occurred in partnership with a private company in the branch of sound and acoustic architecture, located in the city of Salvador - BA. The company added PET-recycled wool to the shutters, turning them into acoustic insulators for acoustic comfort. Therefore, some commercial establishments in Bahia can be found using these artifacts as an integral part of their physical structure, such as auditoriums and churches (Figures 2 and 3).

\section{4) Evaluation phase}

The last phased comprises an evaluation of the whole action research process, being conducted concomitantly to each of the steps to adjust the actions under development. The evaluation occurred soon after the introduction of the product into the market in 2015. The results were analyzed during the evaluation and from it, new strategies for product improvement were proposed.

The mediate evaluation occurs systematically, through meetings and seminars, in which community members, researchers, undergraduate and graduate students whom are involved in the project participate, as well as volunteers (Figure 4). These meetings encompass discussions about factors that may facilitate or hinder the production and marketing of products, as well as about improvement strategies and new technological proposals. Because of mediate evaluation, the product is being patented.

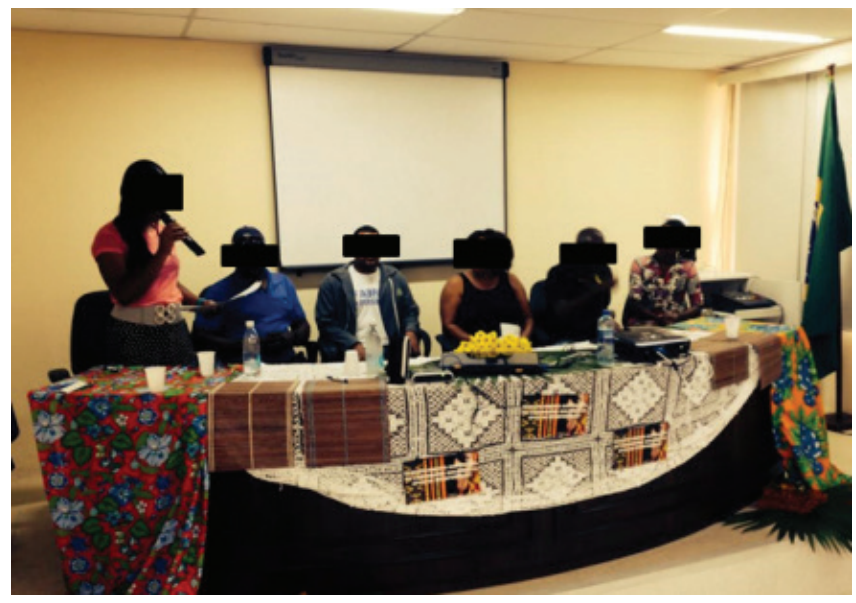

Figure 4 - Meeting of researchers and community members involved in the project to conduct a mediate evaluation, Salvador, Bahia, Brazil, 2016

\section{DISCUSSION}

The relevance of innovative actions is to identify and intervene in the complex conditions that have influence on the diagnosis of diseases in a way that transcends the individual sphere, addressing the collective demands in social, cultural, economic and environmental aspects for the promotion of health in its broadest sense ${ }^{(1)}$.

Promotion of health is considered a field of possibilities in which the macro determinants of health and disease must be identified and faced, seeking to transform individual decision-making processes into collective deliberations to favor the improvement of health and well-being conditions. Stimulating the protagonism of inhabitants to articulate technical and popular knowledge, as well as the mobilization of institutional, community, public and private resources to promote sustainability through social technologies of reuse 
of waste. Such knowledge was innovative when considering the studied community ${ }^{(8)}$.

Similarly to our study, using waste materials to produce engineering artifacts has been showed as positive in a research ${ }^{(9)}$ conducted in São Paulo, in which the incorporation of mortar waste was positive in the manufacture process of soil cement. The product improved in quality and there was reduction in use of the main raw material, leading to environmental preservation and sustainable development.

Community development based on sustainable actions, which was part of this study, was conducted in Venezuela ${ }^{(10)}$, which considered nutrition as the basis for this type of development, by integrating several communities, a university and other institutions. Such cooperation was cited as responsible for lifestyle changes in the population and improvements in the quality of life of the participating communities.

Social technologies from this research are represented by the use of abundant piassava and dendê residues, ensuring sustainable development, which can be characterized as economically sustainable (efficient), socially desirable (inclusive) and ecologically safe (balanced) for preserving the environment ${ }^{(11-12)}$. Before the actions, the residues were discarded in nature without becoming a source of income for the inhabitants, instead, generating environmental pollution.

Researchers in a city of the state of Maranhão also helped to develop environmental preservation and income generation. Their study confirmed that the collection, processing and reuse of waste from the construction industry in a recycling plant were a factor in the reduction of use of raw material, leading to financial gains and minimizing the volume of waste destined for dumps and landfills, which is environmentally advantageous ${ }^{(13)}$.

We must highlight that the use of social technologies in the studied community represented the opportunity of starting a sustainable process of economic growth, distributing income without causing negative impacts on the environment. This was the condition for a development based mostly on the endogenous forces of that locality, empowering the study participants and having the potential to promote social development, although in medium to long term, thus reducing inequalities ${ }^{(13)}$.

Other similar experiences emphasized sustainable activities from the social perspective, showing reduction in inequalities, development of popular and solidarity economy as alternatives for social inclusion by generating work posts and income, as well as the better understanding of those involved regarding their participation in decision-making processes at social, environmental and economic levels, based on self-management practices ${ }^{(14-15)}$.

Initiatives that sought to promote sustainability and social development have favored the empowerment of social actors in the individual and collective spheres, the organization of the communities involved and the strengthening of leaderships ${ }^{(16-17)}$.

These strategies result in social development, which positively impacts individual and collective health aspects. However, we must stress that, as well as in other locations where similar processes were conducted, awareness-raising actions about the preservation of the environment through sustainable actions must be continuous so the execution and maintenance of the actions can be reproduced autonomously.

\section{Study limitations}

The major limitation of the study is the rotation of the participants, hindering the better evaluation of economic development since the financial return is expected to occur from medium to long term. The bureaucracy in the patenting process of the productions is another limitation, due to limiting the possibility of expanding the market, which restricts the financial return in the short and medium term, discouraging the permanence of inhabitants in the project.

\section{Contributions to the field of Nursing}

The study proposal is an innovative initiative in the context of nursing research by providing researchers with the experience of conducting health education activities and approaching the community in a multidisciplinary way, as well as the exchange between popular and scientific knowledge. Furthermore, the use of social technology and income growth empowered the community inhabitants, increasing their autonomy and selfesteem by enabling their access to consumer goods that can promote health.

\section{FINAL CONSIDERATIONS}

Satisfactory results in the use of low-cost strategies, such as social technologies, in the perspective of promotion of health, sustainability and social development of vulnerable communities, are characterized as beneficial, since they provide better quality of life for the population, favoring social, economic and environmental well-being, as well as contributing to increase the inhabitants' human development index.

The critical analysis of the implemented actions, based on sustainability as a mechanism for improving the quality of life and promotion of health, allowed the use of social technologies to be shown as a new form of nursing practices. The promotion of health derived from the participant's sustainable development and valorization of the potentialities of the social actors and abundant natural resources available at the location.

In addition to the socio-economic development and promotion of health, the involvement of nursing in health actions from sustainable development through the implantation of social technologies enabled the attribution of new meanings to professional care, revealing new care models that are different from the predominant model that has gravitated around the health area for many years, favoring the discovery of new fields for the practice and participation of nursing in the construction of a more democratic society.

Considering the positive results from the application of nursing in seeking the promotion of health through sustainable development, we recommend the reproduction of similar actions in different places, especially in communities characterized by vulnerability, such as the one where this research was developed.

\section{FUNDING}

This research was funded by the Fundação de Amparo à Pesquisa do Estado da Bahia (Fapesb) and the Conselho Nacional de Desenvolvimento Científico e Tecnológico (CNPq). 


\section{REFERENCES}

1. Oliveira EF, Jesus VS, Siqueira SMC, Alves TA, Santos IM, Camargo CL. Promoting health in vulnerable communities: social technologies for poverty reduction and sustainable development. Rev Gaúcha Enferm[Internet]. 2015[cited 2016 Feb 23];36(Spe):2006. Available from: http://www.scielo.br/pdf/rgenf/v36nspe/en_0102-6933-rgenf-36-spe-0200.pdf

2. Singh SR, Eghdami MR. The Concept of Social Vulnerability: a review from Disasters Perspectives. Int J Interdiscip Multidiscip Stud[Internet]. 2014[cited 2017 Jan 17];71-82. Available from: http://www.ijims.com/uploads/2a1a7b4810a19951ea42z10.pdf

3. Santos DS, Tenório EA, Brêda MZ, Mishima SM. The health-disease process and the family health strategy: the user's perspective. Rev Latino-Am Enfermagem[Internet]. 2014 [cited 2017 Mar 03];22(6):918-25. Available from: http://www.scielo.br/pdf/rlae/ v22n6/0104-1169-rlae-0002-2496.pdf

4. Rocha PR, David HMSL. Determination or determinants? a debate based on the Theory on the Social Production of Health. Rev Esc Enferm USP[Internet]. 2015[cited 2016 Jun 12];49(1):127-33. Available from: http://www.scielo.br/pdf/reeusp/v49n1/00806234-reeusp-49-01-0129.pdf

5. Mascarenhas NB, Melo CMM, Fagundes NC. Produção do conhecimento sobre promoção da saúde e prática da enfermeira na Atenção Primária. Rev Bras Enferm[Internet]. 2012[cited 2017 Jul 31];65(6):991-9. Available from: http://www.scielo.br/pdf/reben/ v65n6/a16v65n6.pdf

6. Maciel ALS, Fernandes RMC. Tecnologias sociais: interface com as políticas públicas e o Serviço Social. Serv Soc Soc[Internet]. 2011[cited 2017 Mar 08];(105):146-65. Available from: http://www.scielo.br/pdf/sssoc/n105/09.pdf

7. Krumeich A, Meershoek A. Health in global context; beyond the social determinants of health? Glob Health Action[Internet]. 2014[cited 2016 Oct 05];7. Available from: https://www.ncbi.nlm.nih.gov/pmc/articles/PMC3925817/pdf/GHA-7-23506.pdf

8. Borde E. Hernández-Álvarez M, Porto MFS. Uma análise crítica da abordagem dos Determinantes Sociais da Saúde a partir da medicina social e saúde coletiva latino-americana. Saúde Debate[Internet]. 2015[cited 2016 Nov 26];39(106):841-54. Available from: http://www.scielo.br/pdf/sdeb/v39n106/0103-1104-sdeb-39-106-00841.pdf

9. Siqueira SMC, Jesus VS, Santos ENB, Whitaker MCO, Sousa BVN, Camargo CL. Extension activities, health promotion and sustainable development: the experience of a nursing research group. Esc Anna Nery[Internet]. 2017[cited 2017 Jul 19];21(1):1-7. Available from: http://www.scielo.br/pdf/ean/v21n1/en_1414-8145-ean-21-01-e20170021.pdf

10. Griggs D, Stafford-Smith M, Gaffney O, Rockström J, Öhman M, Shyamsundar P, et al. Policy: sustainable development goals for people and planet. Nature[Internet]. 2013[cited 2017 Mar 5];495:320-2. Available from: https://www.nature.com/polopoly_fs/1.20075!/ menu/main/topColumns/topLeftColumn/pdf/534320a.pdf

11. Villanueva MP, Poleo-Camejo GA, Mendoza NJ, Yamilet-Segovia Z, Berné-Peña Y, Pérez-Zambrano ST. Nutrición, base del desarrollo sustentable para el municipio Andrés Eloy Blanco del Estado Lara, Venezuela: creando cultura para vivir en salud. Rev Esp Nutr Comunitaria[Internet]. 2010[cited 2016 Sep 14];16(1):17-20. Available from: http://dx.doi.org/10.1016/S1135-3074(10)70006-5

12. Karpinski LA, Pandolfo A, Reinehr R, Guimarães J, Pandolfo L, Kurek J, et al. Gestão de resíduos da construção civil: uma abordagem prática no município de Passo Fundo-RS. Est Tecnol[Internet]. 2008[cited 2016 Dec 10];4(2):69-87. Available from: http://revistas. unisinos.br/index.php/estudos tecnologicos/article/view/5494/2728

13. Romeiro AR. Sustainable development: an ecological economics perspective. Estud Av[Internet]. 2012[cited 2016 Feb 13];26(74):6592. Available from: http://www.scielo.br/pdf/ea/v26n74/en_a06v26n74.pdf

14. Silva MA, Santos VAA. Reciclagem e Reaproveitamento de resíduos sólidos da construção civil em São Luís - MA: um processo sustentável. Revista do CEDS Periódico do Centro de Estudos em Desenvolvimento Sustentável da UNDB[Internet]. 2014[cited 2017 May 5];1. Available from: http://www.undb.edu.br/ceds/revistadoceds

15. Santos AMM, Deluiz N. Economia popular e educação: percursos de uma cooperativa de Reciclagem de lixo no Rio de Janeiro. Trab Educ Saúde[Internet]. 2009[cited 2017 May 6];7(2):329-53. Available from: http://www.scielo.br/pdf/tes/v7n2/08.pdf

16. Postai Neta MV, Farias MRS, Nunes EM, Santos NN, Marrocos RC, França ARM. Alternativa de conservação ambiental, ocupação e geração de renda em comunidades rurais do território Açu-Mossoró (RN). Rev Extendere[Internet]. 2015[cited 2017 Aug 2];3(1):11840. Available from: http:// http://periodicos.uern.br/index.php/extendere/article/viewFile/1641/892.pdf

17. Setti AFF, Bógus CM. Participação comunitária em um programa de intervenção em área de proteção ambiental. Saúde Soc[Internet]. 2010[cited 2016 Nov 04];19(4):946-60. Available from: http://www.scielo.br/pdf/sausoc/v19n4/20.pdf 